\title{
Bone metastasis in prostate cancer: Molecular and cellular mechanisms (Review)
}

\author{
LIN YE ${ }^{1}$, HOWARD G. KYNASTON ${ }^{2}$ and WEN G. JIANG ${ }^{1}$ \\ ${ }^{1}$ Metastasis and Angiogenesis Research Group, Department of Surgery, Wales College of Medicine, Heath Park, Cardiff; \\ ${ }^{2}$ Department of Urology, University Hospital of Wales, Heath Park, Cardiff, UK
}

Received February 16, 2007; Accepted March 22, 2007

\begin{abstract}
Prostate cancer is the most common cancer in men in Western countries, with a high incidence of bone metastasis. The bony metastasis is incurable and contributes significantly to disease-specific morbidity and mortality. The molecular and cellular mechanisms leading to the development of bone metastasis in prostate cancer remain unclear, but are currently under intensive investigation. In this review, we summarized the current understanding of bone metastasis in prostate cancer. The rapid progress in the genetic predisposition that makes prostate cancer cells more prone to spread to bone, bone-derived factors which are involved in the development of bone metastasis at the level of the local microenvironment, the interactions between metastatic prostate cancer cells and bone marrow endothelial cells, osteoblasts, and osteoclasts, are discussed in this article.
\end{abstract}

\section{Contents}

1. Introduction

2. The modes of disseminating prostate cancer

3. The process of bone metastasis from prostate cancer

4. The orientation of metastases to bone in prostate cancer

5. Non-collagen proteins (NCPs)

6. Bone formation and resorption

7. Tumour-derived osteotropic factors contribute to the predominantly osteoblastic metastases in prostate cancer

8. The vicious cycle of osteoblastic metastases in prostate cancer

9. The role of osteolytic activity in bone metastases of prostate cancer

Correspondence to: Dr Lin Ye, Metastasis and Angiogenesis Research Group, University Department of Surgery, Wales College of Medicine, Cardiff University, Heath Park, Cardiff CF14 4XN, UK

E-mail: yel@cf.ac.uk

Key words: prostate cancer, cancer biology, bone metastasis
10. The pivotal role of bone morphogenetic proteins (BMPs) in bone metastasis from prostate cancer

11. Conclusions and perspectives

\section{Introduction}

Prostate cancer is the most commonly diagnosed male cancer in the UK, the US and in most other Western countries. More than 30,000 new cases are diagnosed each year in the UK alone. It is also the second leading cause of mortality from cancer after lung cancer in men in the UK, accounting for 10,100 deaths each year (1).

Bone metastases are a frequent complication of certain solid tumours. Breast cancer and prostate cancer have the highest frequency of bone involvement, as well as lung and kidney involvement with less frequency. Bone is the most common metastatic site of prostate cancer; $~ 90 \%$ of patients with advanced prostate cancer (haematogenous metastasis) have skeletal metastasis (2). Importantly, once tumours metastasize to bone, they are virtually incurable and result in significant disease morbidity prior to a patient's death. Bone metastases can lead to pain, pathological fractures, nerve compression syndromes, and hypercalcemia. Current treatments are mainly palliative. Although a century ago, Peget proposed the 'seed and soil' hypothesis to describe cancer metastasis (3), knowledge in this critical area remains weak. However, recent years have seen a rapid progress in elucidating the role of certain signal pathways, epithelialmesenchymal transition (EMT), interaction between tumour cells and bone tissue, and certain protein factors in the development of bone metastasis. This article aims to provide an overview of the progress in these areas.

\section{The modes of disseminating prostate cancer}

At an early stage, prostate cancer cells are confined to the prostate gland within the thin surrounding capsule. As the disease progresses, some cancer cells, as the result of genetic predisposition or environmental interaction/stimulation or indeed the combination of both elements, become more aggressive and begin to breach the surrounding structure. These cells either directly invade the surrounding tissue, or disseminate via lymphatic and haematogenous routes. The direct invasion may result in the direct spreading of cancer 
cells to the erectile nerves, seminal vesicles, bladder and rectum situated near the prostate. The lymphatic and vascular routes, however, frequently result in the systemic spread of cancer cells to distant organs, including the bones, lung, and liver.

The primary lymphatic drainage of the prostate is via the internal iliac, perivesical, external iliac, obturator, and presacral nodes. The secondary lymphatic drainage includes the inguinal, common iliac and para-aortic nodes. These nodes are therefore prime locations where one searches for involved positive lymph nodes. At the end of the last century, a new technique, sentinel lymph node dissection, was developed and introduced in the detection, staging and management of lymph node involvement in prostate cancer. The detection of a positive sentinel node indicates the need for a wide dissection of lymph nodes during surgery. However, a convincing negative sentinel node may spare an extensive procedure of dissection, thus avoiding certain complications associated with wide dissection during radical prostectomy (4).

Both lymphatic and haematogenous dissemination frequently occur, even during the early stage of the disease, and are seen in a vast majority of the patients who have advanced prostate cancer. How to determine if systemic spread has 'occurred' or not is a highly controversial topic, a conclusion dependent on a wide variety of factors, from the type of samples to test, location and timing of sampling, techniques to detect cancer cells, to the interpretation of 'the presence of cancer cells or a cancer cell' in a sample. This topic is beyond the realm of the current discussion. Nonetheless, the bone, lung and liver are the leading haematogenous sites of prostate cancer where it is more likely to find a metastatic prostate cancer cell (2).

\section{The process of bone metastasis from prostate cancer}

The process of bone metastasis is complex and arduous, and incorporates multiple cells, factors and stages (Fig. 1). A few reviews summarizing this process have been published (5-7). During the development and progression of the primary tumour, certain clones of tumour cells having acquired genotypic and phenotypic characteristics are able to interact with the local microenvironment. For example, tumour cells release vascular endothelial growth factor (VEGF) to initiate angiogenesis, thus enhancing the blood supply to the tumour. The stromal cells are rich sources of protein factors that directly act on cancer cells thus stimulating the growth of tumours and the dissemination of cancer cells. On the other hand, some of the stromal cell-derived factors directly induce angiogenesis thus supporting the growth and dissemination of an aggressive tumour. A good example of these stromaderived protein factors is hepatocyte growth factor (HGF), a cytokine secreted by the stroma cells, which has been implicated in angiogenesis and the dissemination of tumour cells (8). The disruption of the intercellular adhesion in the tumour causes some tumour cells to detach from the tumour mass (detachment), and then invade the extracellular matrix (invasion) which incorporates the motility, migration of tumour cells and the breakdown of extracellular matrix. Some tumour cells will penetrate the blood vessel, thus

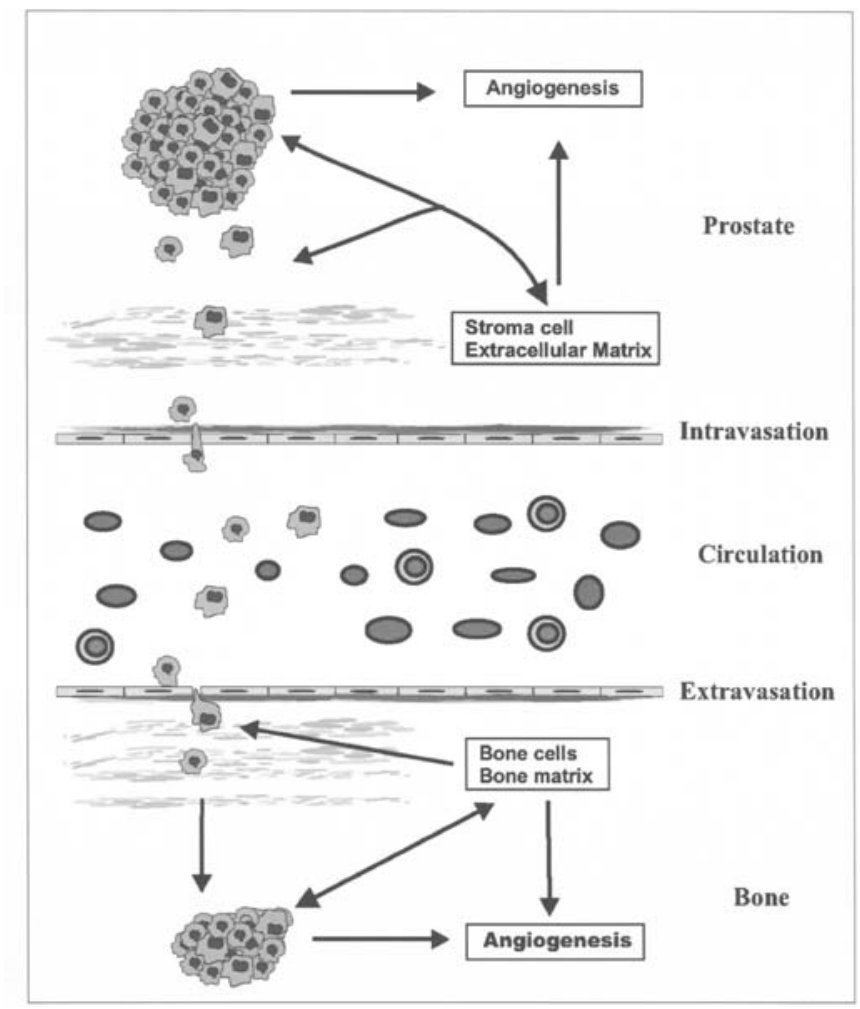

Figure 1. Schematic illustration of the bone metastatic process from prostate cancer.

entering the circulation (intravasation). From this point, these tumour cells migrate from the primary site and circulate in the blood where they are preyed upon by the immune system and the mechanical stresses of blood flow. Some tumour cells eventually survive and adopt a process to leave the blood circulation (extravasation), by which cells adhere and penetrate the blood vessel again (a virtual reversal of the intravasation process). Once the tumour cells escape from the circulation and manage to survive, they finally develop a secondary tumour at another site, in this case in bone. This complex process also needs the integration of multiple factors and events, such as invasion of tumour cells, angiogenesis, interaction between tumour cells and the local microenvironment of bone.

\section{The orientation of metastases to bone in prostate cancer}

The question of why the bone is the most preferred metastatic site of prostate cancer has aroused significant interest in investigation. One would first contemplate the anatomical characteristics of the prostate gland. The blood supply to prostate cancer may provide a shortcut for the haematogenous dissemination of tumour cells from the prostate to certain type of bone. A rich venous plexus surrounds the prostate and connects to the venous drainage of the spine. This collection of veins (Batson's plexus) is potentially one of the reasons why lumbosacral spinal metastases are common in advanced prostate cancer (9). However, the anatomical explanation is unable to explain why the axial skeleton, skull and ribs may also be involved in bone metastasis from prostate cancer. 
The 'seed and soil' theory proposed by Paget may provide some clues from a different standpoint (3). Osteotropic 'seeds' (tumour cells) may be developed during the progression of prostate cancer. These tumour cells may have acquired a specific genetic phenotype, or activation of specific cytokine and proteases. These features direct the metastasis to bone. The elevated expression of bone morphogenetic proteins (BMPs) and TGF- $\beta$ in prostate cancer cells has been implicated in bone metastasis (10-13). The 'seeds' may also attach to the bone endothelium more effectively than to the endothelia of other organs (14). It has been suggested that the protease-activated receptor (PAR1, thrombin receptor) and integrin $\alpha_{V} \beta_{3}$ which are highly expressed in primary prostate cancer cell lines and metastatic prostate cancer cells derived from bone metastasis, may contribute to bony metastases through facilitating the attachment of tumour cells to blood vessel walls and the process of extravasation $(7,15-17)$. The vascular endothelial growth factor (VEGF) secreted by the tumour cells may also contribute to bone metastasis due to both the promotion of angiogenesis and the activation of osteoblasts (18-20).

On the other hand, bone also provides a fertile 'soil' for the 'seeds'. The bone matrix synthesized by osteoblasts is particularly abundant in cytokines and non-collagen proteins, which may attract prostate cancer cells and allow them to survive and proliferate in the bone matrix. For example, BMPs and TGF- $\beta$ which enrich bone matrix can facilitate the development of bone metatstasis. Osteonectin, osteopontin, osteocalcin, and bone sialoprotein can also modulate the properties of prostate cancer cells and facilitate their spreading and growth, including promoting their migration, invasion and proliferation (21-26). Bone turnover as a characteristic of adult bone, occurs most often in bone rich in trabecular bone, such as the vertebrae, proximal femur, calcaneous, and ultradistal radius. During bone turnover, cytokines and non-collagen proteins (NCPs) released or synthesized through bone resorption and bone formation generate a fertile 'soil'. This may also provide an additional insight toward the explanation for probable locations in bone metastases.

\section{Non-collagen proteins (NCPs)}

The bone matrix comprises inorganic and organic parts. The inorganic fraction is mainly crystalline mineral salts and calcium, which is present in the form of hydroxyapatite. The matrix is initially laid down by osteoblasts as unmineralized osteoid. After the subsequent mineralization, osteoblasts secrete vesicles containing alkaline phosphatase to cleave the phosphate groups which later act as the foci for calcium and phosphate deposition.

The organic part of the matrix is mainly type I collagen. This is synthesized intracellularly as tropocollagen and then exported. It then assembles into fibrils. Fibres of this collagen comprise $90 \%$ of the organic material in the mineralized bone matrix. Bone matrix is enriched with various growth factors and cytokines, such as TGF- $\beta 1$ and bone morphogenetic proteins (BMPs). The functions of these factors are not fully known. Bone matrix also contains a number of noncollagenous proteins (NCPs), including fibronectin, osteonectin, thrombospondin-2, Big-h3, bone gla protein (BGP, or osteocalcin), matrix gla protein (MGP), small integrin-binding ligand N-linked glycoproteins (SIBLINGS) and Small Leucine-Rich Proteoglycans (SLRPs).

One of the most abundant NCPs in bone matrix is fibronectin, which is accumulated extracellularly at sites of osteogenesis and plays a profound role in the differentiation, proliferation and survival of osteoblasts (27-29). Osteonectin ('bone connector') was initially called 'bone-specific nucleator' of mineralization as it has high affinity for both collagen and minerals (30). It has been subsequently found to be present throughout the body, particularly at sites of tissue remodelling and matrix assembly. Evidence suggests that it is crucial in maintaining bone turnover (31). Thrombospondin-2 is also abundant in bone, and promotes bone resorption and inhibits bone formation through negative control of the differentiation of bone cell precursors (32-34). Another abundant NCP Big-h3, which is induced by TGF- $\beta$, inhibits the differentiation of osteoblasts through interacting with the integrins $\alpha_{V} \beta_{3}$ and $\alpha_{V} \beta_{5}(35,36)$. Osteocalcin may inhibit bone formation (37), while MGP is a powerful inhibitor of mineralization in arteries and cartilage (38). Members of the SIBLING family include bone sialoprotein (BSP), osteopontin $(\mathrm{OPN})$, dentin matrix protein (DMP), dentin sialophosphoprotein (DSPP) and matrix extracellular protein (MEPE). BSP has been suggested to be involved in hydroxyapatite nucleation (39), and to promote adhesion, differentiation and other biological functions of osteoclasts (40). Osteopontin is crucially involved in anchoring osteoclasts to the mineral matrix of bone surface via the integrin $\alpha_{v} \beta_{3}(41,42)$. Osteopontin is required and probably indispensable during the process of bone resorption $(43,44)$. Nine of the 12 known SLRPs have been found in skeletal tissue (45). The best characterized SLRP in bone is biglycan, which plays an important role in the differentiation of osteoblast precursors (46). It is also involved in osteoblast differentiation induced by BMP-2/4 $(47,48)$.

\section{Bone formation and resorption}

Bone formation and resorption are crucial processes during skeletal development, skeletal homeostasis, turnover of adult bone, fracture and other diseases, particularly during bone metastasis. The process of bone formation (osteogenesis) involves three main steps: production of the extracellular organic matrix (osteoid); mineralization of the matrix to form bone; and bone remodeling by resorption and reformation. There are two categories of factors that are involved in the formation and resorption of bones: systemic hormones/ factors which include parathyroid hormone, 1,25-dihydroxyvitamin D3, thyroxine (T4) and prostaglandins; and local factors such as bone morphogenetic proteins (BMPs), TGF- $\beta$, insulin-like growth factor (IGF), interleukin (IL)-1 and IL-6.

The cellular activities of osteoblasts, osteocytes, and osteoclasts are essential in the process of bone formation and resorption. Osteoblasts synthesize the collagenous precursors of bone matrix and also regulate its mineralization. As the process of bone formation progresses, the osteoblasts come to reside in the tiny spaces (lacunae) within the surrounding mineralized matrix and are then called osteocytes. The cellular 


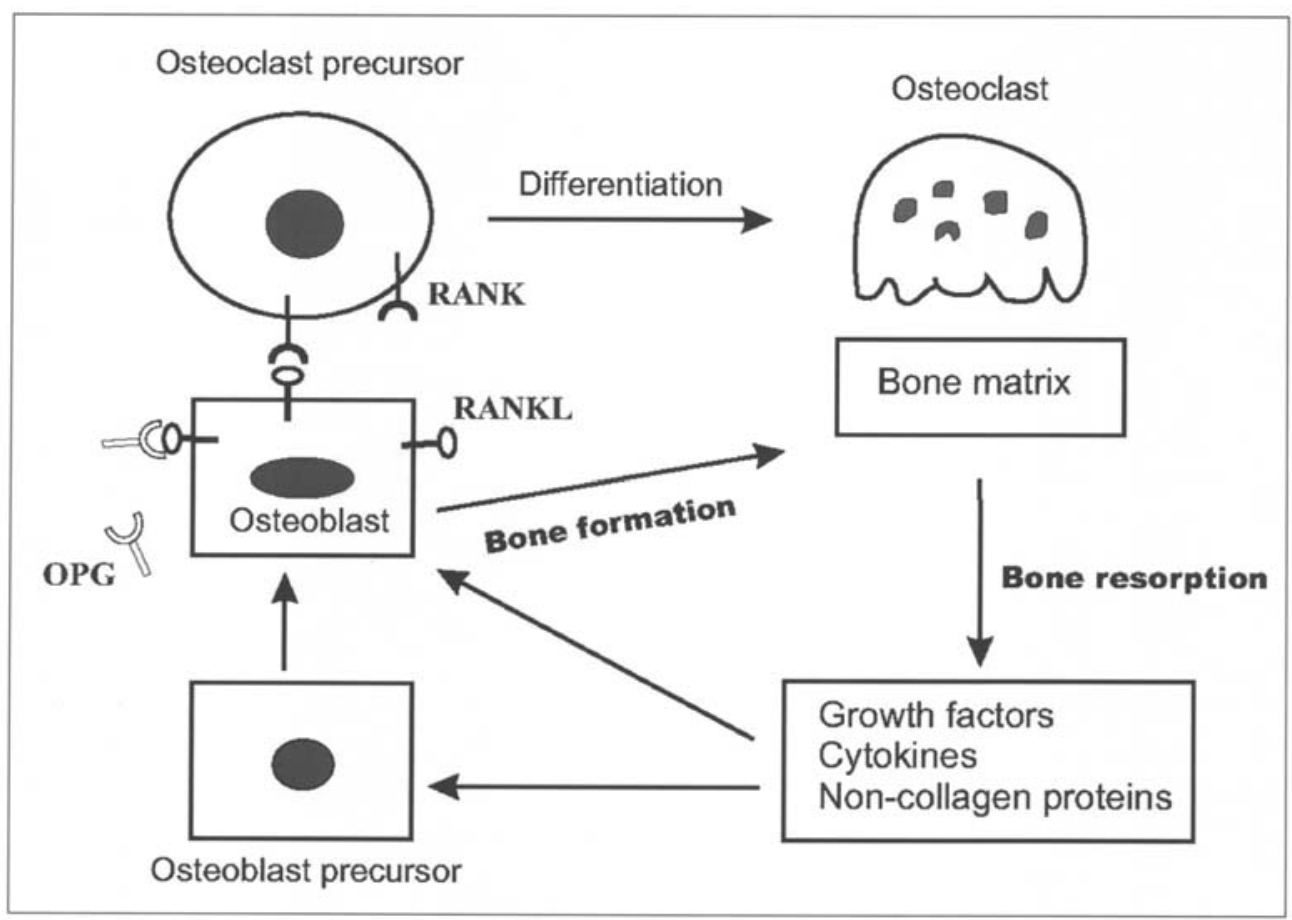

Figure 2. Interactions among the osteoblasts, osteoclasts and bone matrix during bone formation and resorption.

process of osteocytes occupying the minute canals (canaliculi) permits the circulation of tissue fluids. To meet the requirements of skeletal growth and mechanical function, bone undergoes dynamic remodeling by a coupled process of bone resorption by osteoclasts and reformation by osteoblasts. Bone lesions are formed when the regulation of bone mass, which is maintained by a balance between bone-forming osteoblasts and bone-reabsorbing osteoclasts, is perturbed. Details of the molecular interactions between osteoblasts and osteoclasts during the processes of bone formation and resorption have been previously published $(5,6,49)$. Probably, the best understood molecular crosstalk between osteoblasts and osteoclasts is that of RANK and RANKL (Fig. 2). RANK is a transmembrane receptor expressed on osteoclast precursor cells, while RANKL is expressed by osteoblasts which, upon binding to RANK, lead to osteoclast formation. This process can be interrupted by osteoprotegerin (OPG), a soluble competitive decoy receptor for RANKL, which can be secreted by stromal cells, B lymphocytes, dendritic cells and osteoblasts $(50,51)$. This crosstalk also appears to be the mechanism underlying the response of bone to some hormones or local factors, including parathyroid hormone, 1,25-dihydroxyvitamin $\mathrm{D}_{3}$, oestrogen, IL-11 and prostaglandin E2 $(6,49,52,53)$.

\section{Tumour-derived osteotropic factors contribute to the predominantly osteoblastic metastasis in prostate cancer}

Bone metastasis has been characterized as either osteolytic or osteoblastic. This classification actually represents two extremes of a continuum in which dysregulation of the normal bone remodeling process occurs. Patients can have both osteolytic and osteoblastic metastasis or mixed lesions containing both elements. Most metastatic bone tumours from breast cancer have predominantly osteolytic lesions. In contrast, the metastatic lesions from prostate cancer are predominantly osteoblastic. During osteoblastic bone metastases, the balance between bone resorption and bone formation is tipped in favour of the latter. Patients suffer severe bone pain and the poor quality of bone produced in osteoblastic bone metastases frequently leads to bone fractures. Models to investigate osteoblastic metastases are rather rare, compared with models of osteolytic metastasis. The mechanisms which determine the incidence of a metastatic lesion being osteoblastic or osteolytic remain unclear. However, a number of factors produced by cancer cells, such as platelet-derived growth factor (PDGF), insulinlike growth factors (IGFs), fibroblast growth factors (FGFs), VEGF, Wingless and NT-1 (WNT1), parathyroid hormonerelated protein (PTHrP), urokinase-type plasminogen activator (uPA), prostate-specific antigen (PSA), endothelin-1 (ET-1) and BMPs, have been implicated in osteoblastic lesions.

PDGF is a dimeric polypeptide growth factor. Its subunit $\mathrm{A}$ and subunit $\mathrm{B}$ form $\mathrm{AA}, \mathrm{BB}$ and $\mathrm{AB}$ isoforms. The $\mathrm{BB}$ isoform is a potent osteotropic factor, which contributes to osteoblastic lesions through promoting the migration and proliferation of osteoblasts $(54,55)$.

IGF system consists of two ligands, IGF-I and IGF-II, two receptors and seven binding proteins (IGFBPs). IGFs can elicit mitogenic stimulation of osteoblasts, increase bone matrix apposition and decrease the degradation of collagen. Evidence exists to implicate the osteoblast-stimulating factor IGF-I in the formation of metastasis from prostate cancer. First, serum IGF-I levels have been found to correlate with the risk of developing prostate cancer (56), and second, plasma IGFBP-3 levels were lowest in patients with bone metastases, while IGFBP-2 levels were elevated in prostate cancer patients $(57,58)$. Although high IGF-I levels and low IGFBP-3 levels 
may predict the risk of developing advanced-stage prostate cancer (58), a most recent study showed that IGF-I is neither necessary nor sufficient for the osteoblastic response to the metastases of prostate cancer (59). The role of IGF system in bone metastasis of prostate cancer still requires further investigation.

FGFs, both acidic (FGF-1) and basic (FGF-2) are expressed in prostate cancer cells (60). Both FGFs increase the proliferation of osteoblasts, while FGF-2 is able to suppress the formation of osteoclasts (61). The implication of the interplay between these FGFs in bone metastasis remains unclear.

VEGF has been shown to promote bone formation by directly activating osteoblasts and facilitating angiogenesis thus indirectly stimulating the process (62-64). The elevated level of VEGF has been implicated in the development of bone metastasis in prostate cancer (18-20).

WNT1 was elevated in the prostate cancer cells of advanced metastatic prostate carcinoma (65). Wnts produced by prostate cancer cells act in a paracrine fashion to induce osteoblastic activity in bone metastases (66). WNT signaling can be inhibited by its WNT antagonist DKK1 (67). Inhibition of WNT signaling in osteoblasts can suppress osteoblast function and result in the osteolytic phenotype. DKK-1 production occurs early in the development of skeletal metastases, which results in the masking of osteogenic Wnts, thus favoring osteolysis at the metastatic site. As metastasis progresses, DKK-1 expression is decreased, thus allowing the unmasking of Wnt osteoblastic activity and ultimately resulting in osteosclerosis at the metastatic site (66).

PTHrP is an osteolytic factor, which was found abundant in bone metastases of prostate cancer. However, even in metastatic tumours where PTHrP is highly expressed, osteoblastic lesions remain predominant. The explanation for this paradox is that NH2-terminal fragments of PTHrP share strong sequence homology with ET-1, thus stimulating new bone formation by activating the $\mathrm{ET}_{\mathrm{A}} \mathrm{R}(68)$. The osteoblastic fragments of PTHrPs are the products of the cleavage of PTHrPs by prostate-specific antigen (PSA). This provides a partial molecular explanation for the osteoblastic phenotype of PTHrP-positive prostate cancer bone metastases (69).

uPA is also implicated in osteoblastic bone metastasis. uPA produced by prostate cancer cells has been shown to increase the osteoblastic bone metastases $(70,71)$. uPA can cleave and activate TGF- $\beta$ which is produced in a latent form by osteoblasts. TGF- $\beta$ regulates osteoblast and osteoclast differentiation but also regulates the growth of tumour cells themselves. uPAstimulated osteoblast proliferation may also be due to the hydrolysing IGF-binding proteins and a resulting increase in the level of free IGF (72).

PSA is a kallikrein serine protease, which is secreted by prostate cancer cells and used routinely as a marker of prostate cancer progression. PSA not only can cleave PTHrP to release osteoblastic PTHrP fragments, it also activates osteoblast growth factors such as TGF- 3 (73). Like uPA, PSA can also cleave IGFBP-3, thereby IGF-I is capable of binding to its receptor and stimulating osteoblast proliferation $(74,75)$.

MDA-BF-1 is a 45-kDa secreted form of the ErbB3 growth factor receptor (76). Immunohistochemical analyses showed that MDA-BF-1 was expressed in prostate cancer cells that

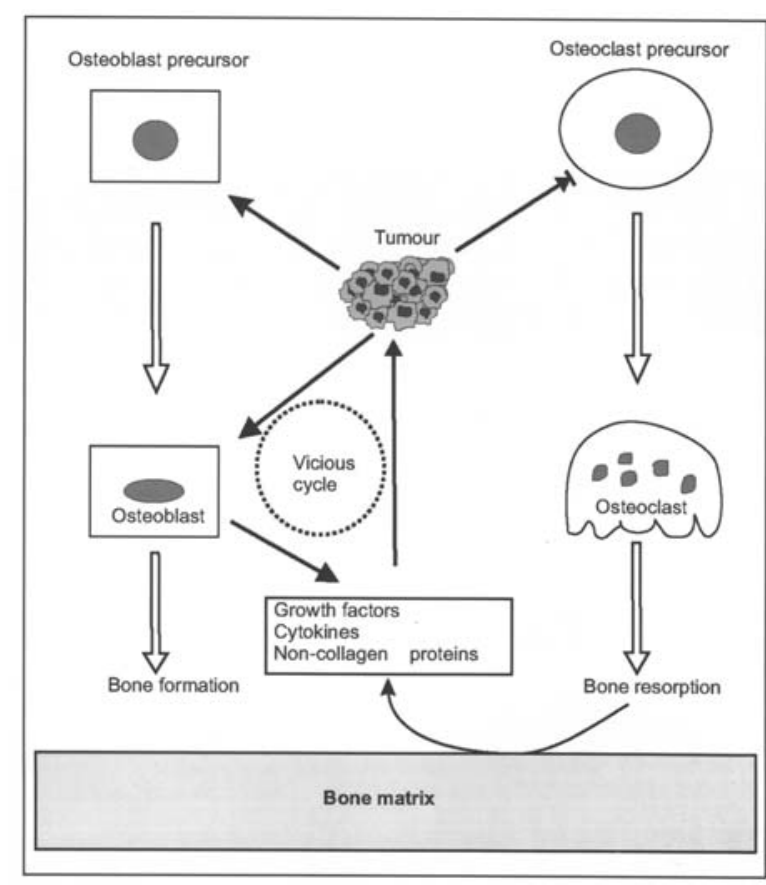

Figure 3. Vicious cycle of the osteoblastic metastasis in prostate cancer. Interactions between tumour and bone microenvironment which includes the osteoblasts, osteoclasts and bone matrix, contribute to the predominant osteoblastic lesions in the bone metastases from prostate cancer.

metastasized to bone, but not in cancer cells from the primary tumours of patients with localized disease (i.e., PCa confined to the prostate). Moreover, MDA-BF-1 was not found in prostate cancer cells that metastasized to the liver, adrenal glands, or lungs. Its function is mediated through a receptor expressed by osteoblasts (77). Further functional studies showed that MDA-BF-1 mediated specific interactions between prostate cancer cells and bone and assisted in the osteoblast-mediated progression of $\mathrm{PCa}$ in bone (78).

ET-1 is a well-known vasoconstrictor, and is also a mitogenic factor for osteoblasts (79). The serum level of ET-1 was found increased in patients with bone osteoblastic lesions (80). ET-1 tends to be elevated in androgen-independent advanced prostate cancers (81). The expression of ET-1 can also be enhanced by bone contact (82). ET-1 has been suggested to be a central mediator of osteoblastic metastasis (83). ET-1 mediates its effects on bone formation through the Endothelin A receptor $\left(E_{A} R\right)$. An $E_{A} R$ antagonist (atrasentan) has been shown to prevent osteoblastic bone metastases in a mouse model and to reduce skeletal morbidity in men with advanced prostate cancer $(84,85)$. ET-1 can increase prostate cancer cell proliferation and enhance the mitogenic effect of other growth factors, including IGF-I, PDGF and EGF (86). Recent evidence suggests that ET-1 increases osteoblast proliferation and new bone formation by activating the Wnt signaling pathway through suppression of the Wnt pathway inhibitor DKK1 (87).

\section{The vicious cycle of osteoblastic metastases in prostate cancer}

During the development of osteoblastic metastasis from prostate cancer, the interactions among tumour cells, bone 
cells and bone matrix constitute a 'vicious cycle' of osteoblast-mediated bone metastasis $(78,88)$. In the early stage of bone metastasis, prostate cancer cells produce osteogenic factors such as ET-1, BMPs and PDGF, to activate osteoblasts. The osteoblasts differentiated from their progenitor cells deposit new matrix for bone formation. However, this unmineralized new matrix provides a more fertile 'soil' for tumour cells, enriched with growth factors and NCPs. These factors help prostate cancer cells survive and proliferate in the bone microenvironment. The prostate cancer cells then further activate osteoblasts. In addition to this vicious cycle, at a certain stage, both tumour-derived factors and osteoblasts expressing RANKL can activate osteoclasts, leading to some level of bone resorption, and subsequently generate bigger spaces for dominant osteoblastic lesions. The cytokines and NCPs released from bone matrix during bone resorption can also enhance this 'vicious cycle' through facilitating the proliferation of both prostate cancer cells and osteoblasts (Fig. 3).

\section{The role of osteolytic activity in bone metastasis of prostate cancer}

It has been demonstrated that osteoblastic metastasis also involves considerable osteolysis $(89,90)$. Both the osteolysis itself and the factors released from bone matrix during bone resorption contribute to the vicious cycle of osteoblastic lesions. In patients with osteoblastic lesions from prostate cancer, blood and urinary levels of bone resorption markers are often elevated (91). Clinical trials have suggested that blocking osteoclastic bone resorption reduces related skeletal events in prostate cancer patients (92). In a mouse model of bone metastasis, the numbers of osteoclasts were shown to markedly increase at sites of early tumour invasion (90). Factors produced by prostate cancer cells within the bone microenvironment, such as RANKL, PTHrP, IL-1, IL-6 and IL-11, may directly or indirectly promote osteoclastogenesis (93). The bone resorption by osteoclasts releases a variety of growth factors, which are stored as inactive forms in the bone matrix. The activation of growth factors may be required by cancer cells to maintain viability and to proliferate and therefore is the key to the establishment of bone metastases. On the other hand, androgen ablation, a standard treatment for prostate cancer, increases osteoclastic bone resorption and bone loss (94-96). The increased bone resorption due to androgen deprivation may result in a more fertile environment for the development of bone metastasis. Bone resorption inhibitors, such as biphosphonates which can prevent bone loss, may also decrease skeletal metastases. Taken together, both osteoblasts and osteoclasts cooperate to actuate the settlement and growth of prostate cancer in bone.

\section{The pivotal role of bone morphogenetic proteins (BMPs) in bone metastasis from prostate cancer}

BMPs belong to the TGF- $\beta$ superfamily. BMPs are the most powerful bone inductive factors which enrich bone matrix (97). BMPs are synthesized not only by osteoblasts and stored in bone matrix, but are also secreted by prostate cancer cells. The aberrant expression of BMPs in prostate cancer has been implicated in the progression of the disease. Primary and metastatic prostate tumours have a different phenotypic pattern of BMP expression and adopt different signaling pathways downstream of the BMP receptor. Most BMPs and their receptors are detectable at a relatively high level in normal prostate tissue. Their expression decreases in a manner that correlates with progression of the primary tumour, except BMP-6 which shows an increase in this case. The expression of BMP-7, GDF15 and BMPR-IB can be induced by exposure to androgens in androgen-sensitive prostate cancer cell lines and in 'normal' prostate epithelial cell lines. The same androgen-inducible effects were not seen with BMP-6 (98-101). Aberrant expression of BMPs and BMPassociated molecules has also been shown to have a prognostic value (102). The pattern of BMP expression has a clear and close relationship with the development and progression of primary prostate tumours and also contributes to the onset and development of bone metastases. For example, BMP-6 remains highly expressed in both primary prostate tumours and metastatic bone lesions. In contrast, BMP-7 and GDF15, which are expressed at low levels in normal prostate and in primary prostate tumours, are re-expressed at a high level in skeletal metastatic lesions. This re-expression in metastatic bone lesion can be seen at a higher level than that in the normal bone tissues around the metastatic lesions $(10,103)$. In addition to the direct stimulation of the aggressiveness of prostate cancer cells, some BMPs are also known angiogenic factors, and thus indirectly facilitate the development of bone metastases via the angiogenic route. Taken together, it is clear that BMPs play a key role in the vicious cycle of metastatic bone formation from prostate cancer. On one hand, prostate cancer cells produce BMPs that activate and induce the osteoblastic activities leading to a predominantly osteoblastic lesion. On the other hand, BMPs synthesized by osteoblasts or released from bone matrix subsequently enhance the growth and aggressiveness of prostate cancer cells, allowing more BMPs to be produced from the tumour cells.

BMPs are partly involved in the occasional osteolytic appearance in bone metastasis. The expression of BMP receptors in prostate cancer cells can also be influenced by stromal factors, such as hepatocyte growth factor (104). In an in vivo bone tumour model, exposure of tumour-bearing subjects to Noggin, an antagonist of BMPs, reduced the size of bone lesions by a mechanism that involved both osteoblastic and osteolytic processes. The BMP antagonists, Noggin and follostatin, are also determining factors in cell response to BMPs. Interestingly, the expression of these antagonists can be regulated by BMPs themselves probably through an autocrine or paracrine feedback loop. A good example is BMP-7, whose endogenous expression is intimately linked to the levels of Noggin and follistatin in the same cell (105). These findings collectively indicate the value of BMPs and their antagonists in the management of bone metastasis.

\section{Conclusions and perspectives}

Men with advanced prostate cancer have a high risk of developing bone metastasis. The interaction between the 
metastatic tumour cells ('seeds') and bone microenvironments ('soil') constitutes a vicious cycle and finally leads to the development of bone metastatic lesions. The metastatic prostate cancer cells, via genetic predisposition (BMP-6 for example) and/or acquired stimulation from the environment, are able to develop a lesion in bone. At the same time, bone matrix (microenvironment) facilitates the adaptation of prostate cancer cells in the 'new home'. The latter involves the bone matrix itself, where matrix components and a variety of factors derived from bone cells attract and facilitate the prostate cancer cells' migration and settlement in bone. This process may be enhanced by bone turnover, aging, and androgen deprivation which release pro-metastatic protein factors in bone matrix. On the other hand, prostate cancer cells in bone undergo changes in order to adapt to the new environment, to survive and to regrow (re-expression of certain BMPs, for example). Once prostate cancer cells settle in the bone environment, they produce factors that are predominantly osteotropic, activate bone formation with some degree of bone resorption, and finally lead to osteoblastic lesions. The subsequent bone formation and resorption generates more factors to further facilitate the process. All these steps constitute the vicious cycle of bone metastasis in prostate cancer.

The study of bone metastasis in prostate cancer is of vital importance and has significantly progressed in the past decade. However, a number of areas remain to be elucidated. For example, it is presently not possible to predict if a prostate tumour will develop bone metastasis from the onset or at an early stage. A molecular signature(s) is yet to be found for this purpose. We have yet to develop suitable models, in vitro and in vivo, that closely mimic bone metastasis for biological investigation and for pre-clinical research. A number of factors are now known to be associated with bone metastasis. Successful development of these factors, either as targets or as therapeutic modalities, is yet to be seen. These are essential areas to explore in the future.

\section{Acknowledgements}

This study was supported by Densa Robbins Jones Charitable Trust, Ralph Shackman Grant Award, Defense Postgraduate Medical Deanery and Cancer Research Wales.

\section{References}

1. CancerStats: CancerStats Incidence UK. Cancer Research UK, 2005.

2. Bubendorf L, Schopfer A, Wagner U, Sauter G, Moch H, Willi N, Gasser TC and Mihatsch MJ: Metastatic patterns of prostate cancer: an autopsy study of 1,589 patients. Hum Pathol 31: 578-583, 2000

3. Paget S: The distribution of secondary growths in cancer of the breast. Cancer Metastasis Rev 8: 98-101, 1989.

4. Wawroschek F, Vogt H, Weckermann D, Wagner T and Harzmann R: The sentinel lymph node concept in prostate cancer - first results of gamma probe-guided sentinel lymph node identification. Eur Urol 36: 595-600, 1999.

5. Raubenheimer EJ and Noffke CE: Pathogenesis of bone metastasis: a review. J Oral Pathol Med 35: 129-135, 2006.

6. Roodman GD: Mechanisms of bone metastasis. N Engl J Med 350: 1655-1664, 2004

7. Cooper CR, Chay CH, Gendernalik JD, Lee HL, Bhatia J, Taichman RS, McCauley LK, Keller ET and Pienta KJ: Stromal factors involved in prostate carcinoma metastasis to bone. Cancer 97: 739-747, 2003.
8. Jiang WG, Martin TA, Parr C, Davies G, Matsumoto K and Nakamura T: Hepatocyte growth factor, its receptor, and their potential value in cancer therapies. Crit Rev Oncol Hematol 53: $35-69,2005$

9. Batson OV: The function of the vertebral veins and their role in the spread of metastases. Clin Orthop Relat Res 312: 4-9, 1995.

10. Masuda H, Fukabori Y, Nakano K, Takezawa Y, T CS and Yamanaka H: Increased expression of bone morphogenetic protein-7 in bone metastatic prostate cancer. Prostate 54: 268-274, 2003.

11. De Pinieux G, Flam T, Zerbib M, Taupin P, Bellahcene A, Waltregny D, Vieillefond A and Poupon MF: Bone sialoprotein, bone morphogenetic protein 6 and thymidine phosphorylase expression in localized human prostatic adenocarcinoma as predictors of clinical outcome: a clinicopathological and immunohistochemical study of 43 cases. J Urol 166: 1924-1930, 2001.

12. Shariat SF, Shalev M, Menesses-Diaz A, Kim IY, Kattan MW, Wheeler TM and Slawin KM: Preoperative plasma levels of transforming growth factor beta(1) (TGF-beta(1)) strongly predict progression in patients undergoing radical prostatectomy. J Clin Oncol 19: 2856-2864, 2001.

13. Autzen P, Robson CN, Bjartell A, Malcolm AJ, Johnson MI, Neal DE and Hamdy FC: Bone morphogenetic protein 6 in skeletal metastases from prostate cancer and other common human malignancies. Br J Cancer 78: 1219-1223, 1998.

14. Lehr JE and Pienta KJ: Preferential adhesion of prostate cancer cells to a human bone marrow endothelial cell line. J Natl Cancer Inst 90: 118-123, 1998.

15. Chay CH, Cooper CR, Gendernalik JD, Dhanasekaran SM, Chinnaiyan AM, Rubin MA, Schmaier AH and Pienta KJ: A functional thrombin receptor (PAR1) is expressed on bonederived prostate cancer cell lines. Urology 60: 760-765, 2002.

16. Kumar CC: Integrin alpha v beta 3 as a therapeutic target for blocking tumor-induced angiogenesis. Curr Drug Targets 4: 123-131, 2003.

17. Cooper CR, Chay $\mathrm{CH}$ and Pienta KJ: The role of alpha(v)beta(3) in prostate cancer progression. Neoplasia 4: 191-194, 2002.

18. Dai J, Kitagawa Y, Zhang J, Yao Z, Mizokami A, Cheng S, Nor J, McCauley LK, Taichman RS and Keller ET: Vascular endothelial growth factor contributes to the prostate cancerinduced osteoblast differentiation mediated by bone morphogenetic protein. Cancer Res 64: 994-999, 2004.

19. Krupski T, Harding MA, Herce ME, Gulding KM, Stoler MH and Theodorescu D: The role of vascular endothelial growth factor in the tissue-specific in vivo growth of prostate cancer cells. Growth Factors 18: 287-302, 2001.

20. Chen J, De S, Brainard J and Byzova TV: Metastatic properties of prostate cancer cells are controlled by VEGF. Cell Commun Adhes 11: 1-11, 2004.

21. Khodavirdi AC, Song Z, Yang S, Zhong C, Wang S, Wu H, Pritchard C, Nelson PS and Roy-Burman P: Increased expression of osteopontin contributes to the progression of prostate cancer. Cancer Res 66: 883-888, 2006.

22. Fizazi K, Yang J, Peleg S, Sikes CR, Kreimann EL, Daliani D, Olive M, Raymond KA, Janus TJ, Logothetis CJ, Karsenty G and Navone NM: Prostate cancer cell-osteoblast interaction shifts expression of growth/survival-related genes in prostate cancer and reduces expression of osteoprotegerin in osteoblasts. Clin Cancer Res 9: 2587-2597, 2003.

23. Jacob K, Webber M, Benayahu D and Kleinman HK: Osteonectin promotes prostate cancer cell migration and invasion: a possible mechanism for metastasis to bone. Cancer Res 59: 4453-4457, 1999

24. Zhang JH, Tang J, Wang J, Ma W, Zheng W, Yoneda T and Chen J: Over-expression of bone sialoprotein enhances bone metastasis of human breast cancer cells in a mouse model. Int $\mathrm{J}$ Oncol 23: 1043-1048, 2003.

25. Denhardt DT, Giachelli CM and Rittling SR: Role of osteopontin in cellular signaling and toxicant injury. Annu Rev Pharmacol Toxicol 41: 723-749, 2001

26. Rosol TJ: Pathogenesis of bone metastases: role of tumorrelated proteins. J Bone Miner Res 15: 844-850, 2000.

27. Moursi AM, Damsky CH, Lull J, Zimmerman D, Doty SB, Aota S and Globus RK: Fibronectin regulates calvarial osteoblast differentiation. J Cell Sci 109: 1369-1380, 1996.

28. Moursi AM, Globus RK and Damsky CH: Interactions between integrin receptors and fibronectin are required for calvarial osteoblast differentiation in vitro. J Cell Sci 110: 2187-2196, 1997. 
29. Globus RK, Doty SB, Lull JC, Holmuhamedov E, Humphries MJ and Damsky CH: Fibronectin is a survival factor for differentiated osteoblasts. J Cell Sci 111: 1385-1393, 1998.

30. Termine JD, Kleinman HK, Whitson SW, Conn KM, McGarvey ML and Martin GR: Osteonectin, a bone-specific protein linking mineral to collagen. Cell 26: 99-105, 1981.

31. Delany AM, Amling M, Priemel M, Howe C, Baron R and Canalis E: Osteopenia and decreased bone formation in osteonectin-deficient mice. J Clin Invest 105: 915-923, 2000.

32. Bornstein P, Armstrong LC, Hankenson KD, Kyriakides TR and Yang Z: Thrombospondin 2, a matricellular protein with diverse functions. Matrix Biol 19: 557-568, 2000.

33. Hankenson KD and Bornstein P: The secreted protein thrombospondin 2 is an autocrine inhibitor of marrow stromal cell proliferation. J Bone Miner Res 17: 415-425, 2002.

34. Hankenson KD, James IE, Apone S, Stroup GB, Blake SM, Liang X, Lark MW and Bornstein P: Increased osteoblastogenesis and decreased bone resorption protect against ovariectomy-induced bone loss in thrombospondin-2-null mice. Matrix Biol 24: 362-370, 2005.

35. Thapa N, Kang KB and Kim IS: Beta ig-h3 mediates osteoblast adhesion and inhibits differentiation. Bone 36: 232-242, 2005.

36. Skonier J, Bennett K, Rothwell V, Kosowski S, Plowman G, Wallace P, Edelhoff S, Disteche C, Neubauer M, Marquardt H, et al: Beta ig-h3: a transforming growth factor-beta-responsive gene encoding a secreted protein that inhibits cell attachment in vitro and suppresses the growth of $\mathrm{CHO}$ cells in nude mice. DNA Cell Biol 13: 571-584, 1994.

37. Ducy P, Desbois C, Boyce B, Pinero G, Story B, Dunstan C, Smith E, Bonadio J, Goldstein S, Gundberg C, Bradley A and Karsenty G: Increased bone formation in osteocalcin-deficient mice. Nature 382: 448-452, 1996.

38. Luo G, Ducy P, McKee MD, Pinero GJ, Loyer E, Behringer RR and Karsenty G: Spontaneous calcification of arteries and cartilage in mice lacking matrix GLA protein. Nature 386: 78-81, 1997.

39. Hunter GK and Goldberg HA: Nucleation of hydroxyapatite by bone sialoprotein. Proc Natl Acad Sci USA 90: 8562-8565, 1993.

40. Ganss B, Kim RH and Sodek J: Bone sialoprotein. Crit Rev Oral Biol Med 10: 79-98, 1999.

41. Hultenby K, Reinholt FP and Heinegard D: Distribution of integrin subunits on rat metaphyseal osteoclasts and osteoblasts. Eur J Cell Biol 62: 86-93, 1993.

42. Reinholt FP, Hultenby K, Oldberg A and Heinegard D: Osteopontin - a possible anchor of osteoclasts to bone. Proc Natl Acad Sci USA 87: 4473-4475, 1990.

43. Ishijima M, Tsuji K, Rittling SR, Yamashita T, Kurosawa H, Denhardt DT, Nifuji A and Noda M: Resistance to unloadinginduced three-dimensional bone loss in osteopontin-deficient mice. J Bone Miner Res 17: 661-667, 2002.

44. Ihara H, Denhardt DT, Furuya K, Yamashita T, Muguruma Y, Tsuji K, Hruska KA, Higashio K, Enomoto S, Nifuji A, Rittling SR and Noda M: Parathyroid hormone-induced bone resorption does not occur in the absence of osteopontin. J Biol Chem 276: 13065-13071, 2001.

45. Young MF: Bone matrix proteins: their function, regulation, and relationship to osteoporosis. Osteoporos Int 14 (suppl 3): 35-42, 2003.

46. Wadhwa S, Embree MC, Bi Y and Young MF: Regulation, regulatory activities, and function of biglycan. Crit Rev Eukaryot Gene Expr 14: 301-315, 2004.

47. Mochida Y, Parisuthiman D and Yamauchi M: Biglycan is a positive modulator of BMP-2 induced osteoblast differentiation. Adv Exp Med Biol 585: 101-113, 2006.

48. Chen XD, Fisher LW, Robey PG and Young MF: The small leucine-rich proteoglycan biglycan modulates BMP-4-induced osteoblast differentiation. FASEB J 18: 948-958, 2004.

49. Sommerfeldt DW and Rubin CT: Biology of bone and how it orchestrates the form and function of the skeleton. Eur Spine J 10 (suppl 2): 86-95, 2001.

50. Hofbauer LC, Khosla S, Dunstan CR, Lacey DL, Boyle WJ and Riggs BL: The roles of osteoprotegerin and osteoprotegerin ligand in the paracrine regulation of bone resorption. J Bone Miner Res 15: 2-12, 2000.

51. Simonet WS, Lacey DL, Dunstan CR, Kelley M, Chang MS, Luthy R, Nguyen HQ, Wooden S, Bennett L, Boone T, Shimamoto G, DeRose M, Elliott R, Colombero A, Tan HL, Trail G, Sullivan J, Davy E, Bucay N, Renshaw-Gegg L, Hughes TM, Hill D, Pattison W, Campbell P, Sander S, Van G, Tarpley J, Derby P, Lee R and Boyle WJ: Osteoprotegerin: a novel secreted protein involved in the regulation of bone density. Cell 89: 309-319, 1997.
52. Guise TA, Mohammad KS, Clines G, Stebbins EG, Wong DH, Higgins LS, Vessella R, Corey E, Padalecki S, Suva L and Chirgwin JM: Basic mechanisms responsible for osteolytic and osteoblastic bone metastases. Clin Cancer Res 12: 6213s-6216s, 2006.

53. Lee SK and Lorenzo J: Cytokines regulating osteoclast formation and function. Curr Opin Rheumatol 18: 411-418, 2006.

54. Mehrotra M, Krane SM, Walters K and Pilbeam C: Differential regulation of platelet-derived growth factor stimulated migration and proliferation in osteoblastic cells. J Cell Biochem 93: 741-752, 2004.

55. Yi B, Williams PJ, Niewolna $\mathrm{M}$, Wang $\mathrm{Y}$ and Yoneda T: Tumor-derived platelet-derived growth factor-BB plays a critical role in osteosclerotic bone metastasis in an animal model of human breast cancer. Cancer Res 62: 917-923, 2002.

56. Chan JM, Stampfer MJ, Giovannucci E, Gann PH, Ma J, Wilkinson P, Hennekens CH and Pollak M: Plasma insulin-like growth factor-I and prostate cancer risk: a prospective study. Science 279: 563-566, 1998.

57. Shariat SF, Lamb DJ, Kattan MW, Nguyen C, Kim J, Beck J, Wheeler TM and Slawin KM: Association of preoperative plasma levels of insulin-like growth factor I and insulin-like growth factor binding proteins-2 and -3 with prostate cancer invasion, progression, and metastasis. J Clin Oncol 20: 833-841, 2002.

58. Chan JM, Stampfer MJ, Ma J, Gann P, Gaziano JM, Pollak M and Giovannucci E: Insulin-like growth factor-I (IGF-I) and IGF binding protein-3 as predictors of advanced-stage prostate cancer. J Natl Cancer Inst 94: 1099-1106, 2002

59. Rubin J, Fan X, Rahnert J, Sen B, Hsieh CL, Murphy TC, Nanes MS, Horton LG, Beamer WG and Rosen CJ: IGF-I secretion by prostate carcinoma cells does not alter tumor-bone cell interactions in vitro or in vivo. Prostate 66: 789-800, 2006.

60. Mansson PE, Adams P, Kan M and McKeehan WL: Heparinbinding growth factor gene expression and receptor characteristics in normal rat prostate and two transplantable rat prostate tumors. Cancer Res 49: 2485-2494, 1989.

61. Dunstan CR, Boyce R, Boyce BF, Garrett IR, Izbicka E, Burgess WH and Mundy GR: Systemic administration of acidic fibroblast growth factor (FGF-1) prevents bone loss and increases new bone formation in ovariectomized rats. J Bone Miner Res 14: 953-959, 1999.

62. Gerber HP, Vu TH, Ryan AM, Kowalski J, Werb Z and Ferrara N: VEGF couples hypertrophic cartilage remodeling, ossification and angiogenesis during endochondral bone formation. Nat Med 5: 623-628, 1999.

63. Street J, Bao M, deGuzman L, Bunting S, Peale FV Jr, Ferrara N, Steinmetz H, Hoeffel J, Cleland JL, Daugherty A, van Bruggen N, Redmond HP, Carano RA and Filvaroff EH: Vascular endothelial growth factor stimulates bone repair by promoting angiogenesis and bone turnover. Proc Natl Acad Sci USA 99: 9656-9661, 2002.

64. Midy V and Plouet J: Vasculotropin/vascular endothelial growth factor induces differentiation in cultured osteoblasts. Biochem Biophys Res Commun 199: 380-386, 1994.

65. Chen G, Shukeir N, Potti A, Sircar K, Aprikian A, Goltzman D and Rabbani SA: Up-regulation of Wnt-1 and beta-catenin production in patients with advanced metastatic prostate carcinoma: potential pathogenetic and prognostic implications. Cancer 101: 1345-1356, 2004.

66. Hall CL, Kang S, MacDougald OA and Keller ET: Role of Wnts in prostate cancer bone metastases. J Cell Biochem 97: 661-672, 2006.

67. Tian E, Zhan F, Walker R, Rasmussen E, Ma Y, Barlogie B and Shaughnessy JD Jr: The role of the Wnt-signaling antagonist DKK 1 in the development of osteolytic lesions in multiple myeloma. N Engl J Med 349: 2483-2494, 2003.

68. Schluter KD, Katzer C and Piper HM: An N-terminal PTHrP peptide fragment void of a PTH/PTHrP-receptor binding domain activates cardiac ET(A) receptors. Br J Pharmacol 132: 427-432, 2001.

69. Cramer SD, Chen Z and Peehl DM: Prostate specific antigen cleaves parathyroid hormone-related protein in the $\mathrm{PTH}$-like domain: inactivation of PTHrP-stimulated cAMP accumulation in mouse osteoblasts. J Urol 156: 526-531, 1996.

70. Achbarou A, Kaiser S, Tremblay G, Ste-Marie LG, Brodt P, Goltzman D and Rabbani SA: Urokinase overproduction results in increased skeletal metastasis by prostate cancer cells in vivo. Cancer Res 54: 2372-2377, 1994. 
71. Rabbani SA, Desjardins J, Bell AW, Banville D, Mazar A, Henkin $J$ and Goltzman D: An amino-terminal fragment of urokinase isolated from a prostate cancer cell line (PC-3) is mitogenic for osteoblast-like cells. Biochem Biophys Res Commun 173: 1058-1064, 1990.

72. Koutsilieris M: Osteoblastic metastasis in advanced prostate cancer. Anticancer Res 13: 443-449, 1993.

73. Killian CS, Corral DA, Kawinski E and Constantine RI: Mitogenic response of osteoblast cells to prostate-specific antigen suggests an activation of latent TGF-beta and a proteolytic modulation of cell adhesion receptors. Biochem Biophys Res Commun 192: 940-947, 1993.

74. Cohen P, Graves HC, Peehl DM, Kamarei M, Giudice LC and Rosenfeld RG: Prostate-specific antigen (PSA) is an insulin-like growth factor binding protein-3 protease found in seminal plasma. J Clin Endocrinol Metab 75: 1046-1053, 1992.

75. Cohen P, Peehl DM, Graves HC and Rosenfeld RG: Biological effects of prostate specific antigen as an insulin-like growth factor binding protein-3 protease. J Endocrinol 142: 407-415, 1994.

76. Vakar-Lopez F, Cheng CJ, Kim J, Shi GG, Troncoso P, Tu SM, Yu-Lee LY and Lin SH: Up-regulation of MDA-BF-1, a secreted isoform of ErbB3, in metastatic prostate cancer cells and activated osteoblasts in bone marrow. J Pathol 203: 688-695, 2004.

77. Liang AK, Liu J, Mao SA, Siu VS, Lee YC and Lin SH: Expression of recombinant MDA-BF-1 with a kinase recognition site and a 7-histidine tag for receptor binding and purification. Protein Expr Purif 44: 58-64, 2005.

78. Choueiri MB, Tu SM, Yu-Lee LY and Lin SH: The central role of osteoblasts in the metastasis of prostate cancer. Cancer Metastasis Rev 25: 601-609, 2006.

79. Takuwa Y, Masaki T and Yamashita K: The effects of the endothelin family peptides on cultured osteoblastic cells from rat calvariae. Biochem Biophys Res Commun 170: 998-1005, 1990.

80. Nelson JB, Hedican SP, George DJ, Reddi AH, Piantadosi S, Eisenberger MA and Simons JW: Identification of endothelin-1 in the pathophysiology of metastatic adenocarcinoma of the prostate. Nat Med 1: 944-949, 1995.

81. Granchi S, Brocchi S, Bonaccorsi L, Baldi E, Vinci MC, Forti G, Serio M and Maggi M: Endothelin-1 production by prostate cancer cell lines is up-regulated by factors involved in cancer progression and down-regulated by androgens. Prostate 49: 267-277, 2001

82. Chiao JW, Moonga BS, Yang YM, Kancherla R, Mittelman A, Wu-Wong JR and Ahmed T: Endothelin-1 from prostate cancer cells is enhanced by bone contact which blocks osteoclastic bone resorption. Br J Cancer 83: 360-365, 2000.

83. Mohammad KS and Guise TA: Mechanisms of osteoblastic metastases: role of endothelin-1. Clin Orthop Relat Res 415: S67-S74, 2003

84. Yin JJ, Mohammad KS, Kakonen SM, Harris S, Wu-Wong JR, Wessale JL, Padley RJ, Garrett IR, Chirgwin JM and Guise TA: A causal role for endothelin-1 in the pathogenesis of osteoblastic bone metastases. Proc Natl Acad Sci USA 100: 10954-10959, 2003.

85. Carducci MA, Padley RJ, Breul J, Vogelzang NJ, Zonnenberg BA, Daliani DD, Schulman CC, Nabulsi AA, Humerickhouse RA, Weinberg MA, Schmitt JL and Nelson JB: Effect of endothelinA receptor blockade with atrasentan on tumor progression in men with hormone-refractory prostate cancer: a randomized, phase II, placebo-controlled trial. J Clin Oncol 21: 679-689, 2003.

86. Nelson JB, Chan-Tack K, Hedican SP, Magnuson SR, Opgenorth TJ, Bova GS and Simons JW: Endothelin-1 production and decreased endothelin B receptor expression in advanced prostate cancer. Cancer Res 56: 663-668, 1996.

87. Clines GA, Mohammad KS, Bao Y, Stephens OW, Suva LJ, Shaughnessy JD Jr, Fox JW, Chirgwin JM and Guise TA: Dickkopf homolog 1 mediates endothelin-1-stimulated new bone formation. Mol Endocrinol 21: 486-498, 2007.
88. Reddi AH, Roodman D, Freeman C and Mohla S: Mechanisms of tumor metastasis to the bone: challenges and opportunities. J Bone Miner Res 18: 190-194, 2003.

89. Oades GM, Coxon J and Colston KW: The potential role of bisphosphonates in prostate cancer. Prostate Cancer Prostatic Dis 5: 264-272, 2002.

90. Yonou H, Ochiai A, Goya M, Kanomata N, Hokama S, Morozumi M, Sugaya K, Hatano T and Ogawa Y: Intraosseous growth of human prostate cancer in implanted adult human bone: relationship of prostate cancer cells to osteoclasts in osteoblastic metastatic lesions. Prostate 58: 406-413, 2004.

91. Garnero P, Buchs N, Zekri J, Rizzoli R, Coleman RE and Delmas PD: Markers of bone turnover for the management of patients with bone metastases from prostate cancer. Br J Cancer 82: 858-864, 2000.

92.Lipton A, Small E, Saad F, Gleason D, Gordon D, Smith M, Rosen L, Kowalski MO, Reitsma D and Seaman J: The new bisphosphonate, Zometa (zoledronic acid), decreases skeletal complications in both osteolytic and osteoblastic lesions: a comparison to pamidronate. Cancer Invest 20 (suppl 2): 45-54, 2002.

93. Vessella RL and Corey E: Targeting factors involved in bone remodeling as treatment strategies in prostate cancer bone metastasis. Clin Cancer Res 12: 6285s-6290s, 2006.

94. Smith MR, Lee WC, Brandman J, Wang Q, Botteman M and Pashos CL: Gonadotropin-releasing hormone agonists and fracture risk: a claims-based cohort study of men with nonmetastatic prostate cancer. J Clin Oncol 23: 7897-7903, 2005.

95. Krupski TL, Smith MR, Lee WC, Pashos CL, Brandman J, Wang Q, Botteman M and Litwin MS: Natural history of bone complications in men with prostate carcinoma initiating androgen deprivation therapy. Cancer 101: 541-549, 2004.

96. Smith MR, McGovern FJ, Zietman AL, Fallon MA, Hayden DL, Schoenfeld DA, Kantoff PW and Finkelstein JS: Pamidronate to prevent bone loss during androgen-deprivation therapy for prostate cancer. N Engl J Med 345: 948-955, 2001.

97. Ye L, Lewis-Russell JM, Kynaston H and Jiang WG: Bone morphogenetic proteins and their receptor signaling in prostate cancer. Histol Histopathol (In press).

98. Ide H, Yoshida T, Matsumoto N, Aoki K, Osada Y, Sugimura T and Terada M: Growth regulation of human prostate cancer cells by bone morphogenetic protein-2. Cancer Res 57: 5022-5027, 1997.

99. Thomas R, Anderson WA, Raman V and Reddi AH: Androgen-dependent gene expression of bone morphogenetic protein 7 in mouse prostate. Prostate 37: 236-245, 1998

100.Kakehi Y, Segawa T, Wu XX, Kulkarni P, Dhir R and Getzenberg RH: Down-regulation of macrophage inhibitory cytokine-1/prostate derived factor in benign prostatic hyperplasia. Prostate 59: 351-356, 2004.

101. Tamada H, Kitazawa R, Gohji K and Kitazawa S: Epigenetic regulation of human bone morphogenetic protein 6 gene expression in prostate cancer. J Bone Miner Res 16: 487-496, 2001.

102.Kim IY, Lee DH, Lee DK, Ahn HJ, Kim MM, Kim SJ and Morton RA: Loss of expression of bone morphogenetic protein receptor type II in human prostate cancer cells. Oncogene 23 7651-7659, 2004

103. Thomas R, True LD, Lange PH and Vessella RL: Placental bone morphogenetic protein (PLAB) gene expression in normal, pre-malignant and malignant human prostate: relation to tumor development and progression. Int J Cancer 93: 47-52, 2001.

104. Ye L, Lewis-Russell JM, Davies G, Sanders AJ, Kynaston H and Jiang WG: Hepatocyte growth factor up-regulates the expression of the bone morphogenetic protein (BMP) receptors, BMPR-IB and BMPR-II, in human prostate cancer cells. Int J Oncol 30: 521-529, 2007.

105. Ye L, Lewis-Russell JM, Kynaston H and Jiang WG: Endogenous BMP-7 controls the motility of prostate cancer cells through regulation of BMP antagonists. J Urol (In press). 